TILTAI, 2015, 1, 127-139, ISSN 1392-3137 (Print), ISSN 2351-6569 (Online)

\title{
KULTŪRINIO SĄMONINGUMO UGDYMAS ${ }^{1}$
}

\author{
Egidijus Stancikas \\ Vytauto Didžiojo universitetas
}

\begin{abstract}
Anotacija
Straipsnyje pristatomos teorinès ižzalgos, siekiant aptarti kultūrinio sąmoningumo ugdymą/si. Straipsnio metodologinès nuostatos: Mezirow perspektyvos transformacijos ir patirtinio mokymosi teorijos. Šių teorijų prieigų pagrindu aptariamas kultūrinio sąmoningumo konceptas, ịvairių autorių apibrezžiamas skirtingai, analizuojamas kultūrinio sąmoningumo turinys ir jo ugdymo/si metodai. Straipsnyje kultūrinio sąmoningumo ugdymas pristatomas kaip suaugusiujų švietimo būdas. Atlikto empirinio tyrimo pagrindu atskleidžiamas suaugusių žiūrovų kultūrinio sąmoningumo kompetencijos lavinimosi vertinimas, jos galimas pritaikomumas.

PAGRINDINIAI ŽODŽIAI: kultūrinis sąmoningumas, ugdymasis, suaugusiųų švietimas.
\end{abstract}

\begin{abstract}
The article introduces the theoretical insights relevant to a discussion of the cultivation of cultural consciousness. It relies on the following methodological precepts: Mezirow's principles of transformational change and experiential learning theories. On the basis of the foregoing principles, the article discusses the concept of cultural consciousness, which various writers define differently, and analyzes the substance of cultural consciousness as well as the methods involved in its cultivation. In the article the cultivation of cultural consciousness is presented as a vehicle for adult education. KEY WORDS: cultural consciousness, cultivation, adult education.
\end{abstract}

DOI: http://dx.doi.org/10.15181/tbb.v69i1.1055

\section{Ivadas}

Kultūra - neabejotinai vienas svarbiausių veiksnių, lemiančių tiek visuomenès išsivystymo lygị, tiek paties žmogaus visavertị socialinị gyvenimą šiuolaikinėje visuomeneje. Paprastai net visuomenès išsivystymo lygis matuojamas, atsižvelgiant ị kultūros veiklos sričių rezultatus. Kultūra tarnauja ịvairių veiklos formų reprodukcijai, akumuliuoja ir transformuoja ịvairias socialinio gyvenimo formas, sudaro iš esmès naują subjekto potencialą, kurio uždavinys - pereiti i aukštesnị visuomenès kultūros ir socialinio gyvenimo lygị. Nuo kultūros kokybès priklauso ir visuomenės augimas, o individo gyvenimo perspektyva - nuo dalyvavimo kultūriniame gyvenime.

1 Mokslinis tyrimas finansuojamas Europos socialinio fondo lešomis pagal visuotinès dotacijos priemonę. 
LR Kultūros ministerijos užsakytam tyrime (Gyventojų dalyvavimo kultūroje ir pasitenkinimo kultūros paslaugomis tyrimas, 2014) pabrèžiama, kad kitose visuomenėse pastebèti dėsningumai galioja ir Lietuvoje, taigi kultūrinėje veikloje dalyvaujantys gyventojai ir kultūrą vartojantieji akivaizdžiai yra visuomeniškesni, laimingesni, jaučiasi sveikesni, labiau pasitiki kitais ir t. t. Be to, minètoje ataskaitoje teigiama, kad tarp dalyvaujančiųų kultūrinejje veikloje šis ryšys yra stipresnis nei tarp vartojančiųjų kultūrą. Kalbant apie kultūros poveikio veiksnius, svarbus ne tik ryšio tarp dalyvavimo / vartojimo bei gyventojų socialumo patvirtinimas, bet ir priežastingumas, t. y. dalyvavimas kultūroje ir jos vartojimas nulemia didesnị socialumą bei stipresnę tapatybę ar atvirkščiai. Maždaug trečdalis tyrime dalyvavusių respondentų mano, kad dalyvaudami kultūrinèje veikloje jie tampa kūrybingesni ir patriotiškesni. Kita vertus, absoliuti dauguma nedalyvaujančiųjų nemano, kad dalyvaudami sustiprintų savo tapatybę ir padidintų kūrybingumą. Tad klausimas lieka neatsakytas, o tarpinè preliminari išvada būtu ta, kad dalyvavimas kultūroje ir jos vartojimas yra būtina, bet nepakankama socialumo ir pilietiškumo sąlyga.

Neabejotina, kad kultūra - tai sąmoningumo ugdymo instrumentas. Tai teigia ir mokslininkai (Chodzkienė, 2012; Melnikova, 2007; Kazragyte, 1994 ir kt.), kurių nuomone, tarp kūrybos, žmogaus ugdymo bei asmens gyvenimo ịūdžių yra nemažai paralelių. Visa tai suponavo mokslinę problemą: kokia yra kultūrinio sąmoningumo samprata ir kas laiduoja jo ugdymąsi?

Tyrimo metodai: mokslinès literatūros analizè, apklausa raštu.

\section{Tyrimo metodologija}

Straipsnyje pateikiami empirinio žvalgomojo tyrimo rezultatai. Kiekybinis tyrimas vykdytas igyvendinant Lietuvos mokslų tarybos dotacijos projektą ,Suaugusiujų bendrujų kompetencijų lavinimo ir plètros platforma“ (Nr. VP1-3.1-ŠMM07-K-03-073).

Empiriniam tyrimui atlikti taikyta apklausa raštu. Tyrimo instrumentas sudarytas remiantis Europos Komisijos orientaciniais metmenimis (Bendrieji visą gyvenimą trunkančio mokymosi gebejjimai: Europos orientaciniai metmenys, 2007). Visi gebejjimai laikomi vienodai svarbiais, nes gali padèti puikiai orientuotis žinių visuomenejje. Daugelis gebejjimų persipina ir papildo vienas kitą: vienai sričiai būdingi aspektai stiprina kitos srities gebẻjimus. Kultūrinio sąmoningumo ir raiškos kompetencijai išsiaiškinti parengtas klausimynas, kurị sudare 8 klausimų blokai (bendrujų kompetencijų aktualumas; demografiniai duomenys; asmenybės kultūrinio sąmoningumo kompetencijos aktualumo ịvertinimas; asmenybès kultūrinio 
sąmoningumo kompetencijos ịgijimo būdai; asmenybès kultūrinio sąmoningumo kompetencijos ịgijimo ir lavinimosi kliūtys; veiksniai, skatinantys lavinti asmenybės kultūrinio sąmoningumo kompetenciją; asmenybès kultūrinio sąmoningumo kompetencijos poveikis asmenų profesiniam gyvenimui [ịsidarbinimui, užimtumo statusui ir kokybei ir kt.]; asmenybės kultūrinio sąmoningumo kompetencijos poveikis asmenų dalyvavimui visuomeninejje veikloje). Anketa pateikta elektronine versija, sukurta laisva prieiga kiekvienam suaugusiajam, todèl respondentai pasirinkti atsitiktiniu būdu. Tyrime dalyvavo 218 ịvairaus amžiaus suaugusiujjų.

\section{Metodologinès nuostatos}

J. Mezyrow $(1997 ; 2000)$ perspektyvos transformacijos teorija. Joje teigiama, kad suaugę žmonės tobulèja pamažu ir nuosekliai restruktūrizuodami diskusijų apibrèžtis, leidžiančias jiems kurti prasmes; žmonių požiūris ị prasmes keičiasi, išklausius kitų žmonių požiūrius, pvz., kultūros renginiai, teatro spektaklio turinys, jo recenzijos, reklama ir t. t. Kai kurių autorių (Zubrickienė, Adomaitienè, 2011; Bulajava, 2007 ir kt.), nagrinejjusių perspektyvos transformacijos teoriją, teigimu, kritinis reflektyvumas ypač aktualus perspektyvos transformacijoje. Issisąmoninimas to, kodẻl suaugusieji suteikia vienokią ar kitokią prasmę juos supantiems tikrovès reiškiniams, ypač savo vaidmenims ir santykiams, - tai prasmių, kurias jie dažnai klaidingai aiškina ir neteisingai interpretuoja, procesas. Perspektyvos transformacija suprantama kaip emancipuojantis procesas, kai žmogus kritiškai ịsisąmonina ir suvokia, kaip ir kodèl psichokultūrinių prielaidų struktūra neleidžia jam teisingai matyti savęs ir savo santykių. Šios struktūros pertvarkymas leidžia atlikti labiau inkliuzyvinę, diskriminuojančią patirties integraciją ir veikti atsižvelgiant ị šị naują suvokimą (Bulajeva, 2007).

Patirtinio mokymosi filosofija, remiantis kai kuriais autoriais (Merriam, Caffarella, Baumgartner, 2007 ir kt.), pagrindinị dẻmesị kreipia ị suaugusius žiūrovus, kurie turi ịvairų formalų ir neformalų išsilavinimą ir asmeninị (kultūinị) kontekstą, juos vienija tai, kad yra suaugę ir turi ilgametę gyvenimo patirtį. Patirtinio mokymosi teorija remiasi situaciniu pažinimu ir enaktyvizmu, pabrèžia kultūrinio veiksmo ir jo analizès vaidmenị bei kritikuoja tuos, kurie mėgina atskirti patirties sąvoką nuo jos socialinių istorinių šaknų.

\section{Kultūrinio sąmoningumo konceptas ir turinys}

Mokslinèje literatūroje (Kolbergytè, Indrašienè, 2012; Gailienè ir kt., 2004 ir kt.) galima aptikti įvairių sąmoningumo atitikmenų: sąmonè, sąmonejjimas, ịsisą- 
moninimas, kritinis sąmoningumas, kritinè sąmonè, kritinis reflektavimas, kritinis mąstymas ir kt. (angl. critical thinking, consciousness-rising (CR), critical consciousness). Tačiau dažniausiai vartojamos dvi sąvokos: siauresne prasme - supratimas, issisamoninimas, informuotumas (angl. self-awareness), jos labiau atskleidžia žinias apie aplinką, domèjimąsi kažkuo; platesniu požiūriu sąmoningumas dažniau išreiškiamas kaip sąmonè, sąmoningumas, supratimas, suvokimas, pajautimas, savimonė (angl. self-consciousness), tai labiau susiję su kritiniu mąstymu, savęs ir aplinkos ịprasminimu ir per tai atsirandančiu suvokimu (Kolbergytė, Indrašienè, 2012). Filosofas R. Descartes žmogų apibūdino kaip mąstančią esybę, kuri abejoja, supranta, teigia, prieštarauja, jaučia. Kalbėdamas apie išorinio pasaulio pažinimą ir suvokimą, filosofas samprotavo, kad pažįstamas ne pasaulis, o mūsų pačių psichinès būsenos ir intelektiniai aktai (Sikora, 2004). R. Descartes garsèjo posakiais: „mąstau, vadinasi, esu“, „abejoju, vadinasi, mąstau“, kurie iliustruoja žmogaus mąstymą ir kritinị sąmoningumą kaip egzistencijos pagrindą.

Sąmoningumo faktai, remiantis analitine filosofija, susiję su žmogaus elgsena, t. y. žmogaus pojūčiais, jausmais, nuostatomis, požiūriais, pomėgiais, norais, įsitikinimais, prisiminimais, motyvais, ketinimais, sprendimais, mintimis, suvokimais, vaizdiniais, svajonemis ir t. t.

Sąmoningumas siejamas su visomis žmogaus gyvenimo sritimis (pradedant saviugda, savęs realizavimu profesinejje veikloje, pereinant prie santykių su šeima, draugais, galiausiai su visuomene). Be to, matyti, kad sąmoningumas susijęs su asmenybès efektyvumo skatinimu (kitaip - savikūra) ir savęs valdymu (kitaip - savivalda, savikontrole), t. y. gebejjimu pritapti visuomenèje, atsakingai elgiantis (siekti savų tikslų, nepažeidžiant kitų žmonių teisių) (Kolbergytė, Indrašienė, 2012).

Pažymètina, kad sąmoningumo formavimas yra proto ir patirties išdava. R. Descartes teigimu, pasaulio pažinimas ir sąmonès formavimas susiję su mąstymu (t. y. protu), o ne su juslemis. Tačiau pragmatinès pažinimo koncepcijos žmones traktuoja kaip kūrybingus ir išradingus pasaulio interpretatorius - pasaulio, kurị kuriame mes patys. Tai reiškia, kad tam tikros sąvokos ir gyvenimo prasmés formuojasi tik atsižvelgiant ị turimą patirtị, kitaip tariant, mes formuojame tokias prasmes, kurias sugebame suvokti bei ịsisąmoninti patirdami išgyvenimus. Vadinasi, visos mūsų sąvokos ir ịsitikinimai gali būti koreguojami pasitelkus mąstymą ir patyrimą. Tai reiškia, kad sąmoningumą reikia sustiprinti vertybėmis, tokiomis kaip atsakomybė, ịsipareigojimas, kitaip tariant, asmuo prisiima individualią atsakomybę pačiam svarstyti, analizuoti, vertinti, priimti ar atmesti tam tikrų reiškinių esmę, nuspręsti, kuo vadovaujantis formuos savo požiūrị bei veiksmus ateityje (Kolbergytė, Indrašienè, 2012).

Mokslinès literatūros analizè (Kolbergytė, Indrašienė, 2012; Bulajava, 2007 ir kt.) leidžia skirti keletą pagrindinių sąmoningumo ugdymo veiksnių: tinkama 
aplinka ir situacija, poreikis įgyti ar gausinti žinias ir galimybių įvardyti patirtis. Taigi sąmoningumo formavimosi procesas priklauso nuo žmogaus patirties ir mąstymo procesų, kuriuos skatina paties žmogaus asmeninė domejjimosi, kas vyksta pasaulyje, motyvacija, tam ịtakos turi ir visuomenès struktūrų poveikis.

Kultūrinị sąmoningumą galime apibūdinti kaip ịvairių kūrybinių idèjų, patirties ir emocijų išraiškų ịvairioje terpejje, įskaitant muziką, scenos meną, literatūrą ir vizualujį meną, svarbos suvokimą (Bendrieji visą gyvenimą trunkančio mokymosi gebėjimai. Europos orientaciniai metmenys, 2007). Kultūrinio sąmoningumo svarbą pažymi A. Maceina (2002). Filosofas teigia, kad kiekvienas žmogus atsakingas už kultūros ir net už viso pasaulio vyksmą: dabar žmogus jau nėra aklas kultūinès pažangos įrankis, bet sąmoningas jos vykdytojas (Maceina, 2002). Žmogus turi prisidèti ten, kur prigimtis apardyta, kur netikslingai veikia jos dèsniai, kur natūrali jų eiga buvo iškreipta pašalinių veiksnių. Čia sąmoningas kultūrinis veikimas turi būti dvejopas: atitaisyti tai, kas iškreipta, kartu stumti priekin šitą „,sužeistajj padarą" (Maceina, 2002, p. 574).

I. Krasner (1999) skiria tris pagrindinius kultūrinio sąmoningumo lygmenis: kultūrinius formalumus (angl. cultural conventions), socialines mandagumo formas (angl. social amenities) ir konotacijas (angl. conno tations). Pirmajai grupei priskiriami pasisveikinimai ir atsisveikinimai, kreipiniai, padèka, komplimentu sakymas bei prièmimas ir pan., kurie visada papildomi neverbalinèmis komunikacijos priemonėmis, tokiomis kaip gestai, mimika, prisilietimai, akių kontaktas ir t. t. Socialinio mandagumo formos, tokios kaip pagyrimas, atsisakymas, įsakymas, skundas ir kt., visada lydimos etiketo normų. Konotacijos - tai sritis, kurioje, pasak mokslininkès, kalba ir kultūra susilieja ir padeda išryškinti kultūrinius skirtumus, čia konotacijos skiriasi atsižvelgiant ị kontekstą.

Mokslinèje literatūroje kultūrinis sąmoningumas įvardijamas kaip vienas pagrindinių komponentų. Autoriai (Mažeikienè, Loher, 2008 ir kt.) kultūrinị sąmoningumą taip pat prilygina aukščiausiam tarpkultūinès kompetencijos lygiui. Jų teigimu, jis apima žinias, nuostatas ir elgesį. Pasak N. Mažeikienès ir D. Loher (2008), tik pasiekus aukštą tarpkultūrinès kompetencijos (žinios, nuostatos, gebejjimai) lygị tikslinga kalbèti apie kultūrinio sąmoningumo išsiugdymą. Kultūrinis sąmoningumas brandinamas mokantis visą gyvenimą. Kaip ir tarpkultūrinè kompetencija jis yra ugdymo(si) rezultatas, kurio siekiama visą gyvenimą. Teatras pasižymi išskirtinèmis galiomis kurti ir formuoti socialinius ryšius, todèl padeda efektyviai atskleisti kultūrinị sąmoningumą. Teatras - palanki erdvè ugdyti žmogaus kūrybiškumą, kritinị mąstymą, leidžiant ịsijausti ị kito žmogaus gyvenimą. Estetinis požiūris aprẻpia visus komunikacinius ir kūrybinius reiškinius, stengiasi atskleisti tai, kas juose yra meniška ir estetiška. 
Analizuodami kultūrinio sąmoningumo konceptą neišvengiamai mąstome apie žmogaus ugdymą kultūroje. U. Eco (Mažeikienè, Loher, 2008) teigimu, pedagoginè meno paskirtis - skatinti sąmonès veiklą, o ši turètų skatinti praktinius veiksmus. Menas leidžia kitaip pažvelgti ị daiktus ir susieti juos naujais ryšiais, kaip santykinį reflektą priimti idejją ir kurti darbinius modelius su daugybe papildomu sprendimų. U. Eco požiūriu, tokie modeliai leidžia suvokti tikrovę, kurią formuoja kultūra. Šiuo požiūriu meno procesai gali suteikti vaizdinių nuorodas, leidžiančias judèti šiame pasaulyje. Kultūros suvokimo pokyčiai kelia naujus reikalavimus ugdymui. Kūrybiškumas yra vidinė pažinimo funkcija, atsiskleidžianti per socialinius ir kultūrinius reiškinius. Kūrybiškumą galime suprasti kaip žmogišką savybę, kuriai įtakos turi kompetencija, kūrybinio mąstymo įgūdžiai ir motyvacija.

\section{Kultūrinio sąmoningumo ugdymas kaip suaugusiųjų švietimas}

Geras savo kultūros išmanymas ir tapatumo jausmas gali būti atviro požiūrio ị kultūrinès raiškos ịvairovę bei pagarbos jai pagrindas. Teigiamas požiūris taip pat reiškia kūrybiškumą ir norą lavinti estetini gebejimą, pasitelkiant meninę saviraišką ir dalyvaujant kultūriniame gyvenime (Bendrieji visą gyvenimą trunkančio mokymosi gebejjimai. Europos orientaciniai metmenys, 2007).

Kultūrinio sąmoningumo ugdymas prilygsta kūrybiškumui, kuris yra visas gyvenimo sritis persmelkianti, visa apimanti žmogaus veikos ypatybė, nepaprastas sugebėjimas, priskirtinas konkrečioms grupėms, individams ar konkrečios veiklos sritims, ypač meninei. Neįmanoma išugdyti kultūrinio sąmoningumo, neugdant savo kūrybiškumo. Remdamiesi daugeliu kūrybiškumo apibrèžimų galime teigti, kad kūrybiškumas yra naujų idèjų kūrimas, sprendimų suradimas arba esminis problemų performulavimas, kas paprastai yra dramos teatro veikla.

Kultūrinio sąmoningumo ugdymasis yra nuolatinis procesas, nukreiptas ị tikslą, kuris arba yra reikšmingas individui, arba naudingas visuomenei. Kūrybinis mąstymas turi skatinti sukurti ką nors naujo, unikalaus. Intelekto sąvoka daug platesne, ji apima ir kitas proto savybes bei gebẻjimus, ne tik mąstymą. Kūrybiniai gebejjimai daug priklauso nuo turimų žinių (ne ịsimintinų, tokių, kuriomis individas gali laisvai operuoti) kiekio ir kokybès.

Kultūrinio ugdymo gairès gali pagerinti bendrą visų interesų grupių supratimą apie meninio ugdymo svarbą ir jo esminę ịtaką švietimo kokybei. Geroji praktika kultūrinio ugdymo srityje yra praktinis požiūris, kuris galètų tapti nuolat tobulinamu baziniu dalyku. Čia atsiskleistų konkretūs pokyčiai ir žingsniai, būtini siekiant strategiškai iggyvendinti meninio ugdymo planus švietimo (formalaus ir neformalaus) sistemoje. Būtų galima sukurti tvirtą pagrindą, kuriuo remiantis ateityje būtų 
priimami sprendimai ir atliekami veiksmai šioje srityje. Meninè kūryba yra natūralus kiekvieno kultūringo žmogaus poreikis, skatinantis asmens kūrybinių galių sklaidą. Tai vienintelis tam tikrų pasaulio aspektų pažinimo ir buvimo jame būdas, kurio negalima pakeisti kitu. Kultūra ir jos formos suteikia galimybę savitai išreikšti vidinị pasaulị ir reaguoti ị aplinką, moko kūrybiškai veikti ir mąstyti.

Kultūriniu ugdymu siekiama ne pristatyti meno, kultūros turtus, bet atgaivinti, praturtinti ugdytinių pojūčius, atskleisti besimokančiojo vidines galias, veiksmingai ir harmoningai ugdyti asmenybę. Kultūros paskirtis šiame amžiuje - puoselèti ugdytinio menini jautrumą, padèti jam atskleisti, pajusti bendravimo ir asmeninès kūrybos džiaugsmą.

Kultūros pedagogikos pagrindiniai tikslai, kaip ir suaugusiujų švietimo, diegti žmonėms vertybes, mokyti suvokti savus poreikius, pareigas ir viską, kas siejasi su žmonija. V. Matonio (2000) teigimu, žmogu galima pažinti ir suprasti per istoriją ir kultūrą, kuri aktyvina jo dvasinius poreikius. Kultūra ir jos supratimas yra istoriški. Kad ir ką sakytų menotyrininkai bei estetikai apie meninès kultūros pasaulio savarankiškumą, kultūra visada egzistuoja konkrečioje visuomenèje ir yra glaudžiai susijusi su epochos dvasia. Ji išreiškia savo laiką, racionalumo ir emocionalumo atmosferą, kuri viešpatauja aplinkui, žmonių idealus ir orientyrus. Visa tai kultūra pateikia savitu pavidalu, kuris nedubliuoja tiesiogiai egzistuojančių socialinių santykių, tačiau laikmečio atspaudas aiškiai matomas ne tik literatūroje, teatro kūriniuose, bet ir muzikoje, dailëje, skulptūroje.

Teigtina, kad kultūrinis ugdymas, pasireiškiantis per meną, tapybą, poeziją, kiną ir kitus kūrinius, lavina suaugusiojo estetinị skonị, suteikia būtinų kultūrinių žinių. Suaugusiujų švietimo procese galima taikyti ištisą kultūrinių metodų paletę: psichodramos elementus, dramaturgijos kūrimą, lèlių teatrą ir t. t. (Čeredaitè, 2006). J. L. Moreno (Čeredaité, 2006) sugalvoti psichodramos elementai, kaip apsikeitimas vaidmenimis, vaidmenų repetavimas, veidrodis, dubliavimas ir kt., padeda ịsigilinti ị žmogaus mintis, suvokti esamas problemas ir ieškoti būdų, kaip jas spręsti. Vaidmenų metodas apibūdinamas kaip laisvas, spontaniškas, kūrybinis, socialinis dalyvių žaidimas pagal pačių pasirinktus siužetus, vaidmenis, savarankiškai plètojant turinį, atliekant veiksmus su daiktais ir žmonėmis. Europoje, ypač Anglijoje ir Skandinavijos šalyse, plačiai taikomi interaktyvūs dramos metodai populiarèja ir Lietuvoje. Kadangi terminai nèra nusistovèję, šie metodai ịvardijami skirtingai: proceso drama, taikomasis teatras, socialine drama, forumo teatras ir kt. Proceso drama yra vienas iš teatro žanrų ịtraukiant žiūrovus, kur pagrindinis vaidmuo tenka dalyviams. Proceso dramos tikslas - naudojant asmeninị patyrimą didinti empatiškumą (gebejjimą suprasti kito jausmus ir požiūrį, elgesio priežastis), keisti savo iracionalius ịsitikinimus, nuostatas ir neveiksmingas elgesio strategijas. Šis metodas sèkmingai taikomas socialinių kompetencijų didinimo, konfliktų 
sprendimo, komandos darbo gerinimo, probleminių asmenų elgesio korekcijos ir daugelyje kitų socialinės komunikacijos sričių. Dalyvių tikslas - vaidinant atrasti tam tikro reiškinio ir svarbaus jų gyvenimo įvykio ryšį. Proceso dramos metodas skatina mokymosi motyvaciją, didina pasitikèjimą savimi, padeda lavinti tarpasmeninius ir socialinius santykius, žadina vaizduotę ir jausmus, suteikia galimybę mokytis įvairių dalykų patrauklia forma.

Instrumentinio požiūrio ị vaidybos meną laikosi vadinamoji drama, suprantama kaip dalykų mokymo(si) metodas ir kaip savita vaidybinio ugdymo kryptis.

Ivairiais meno mokymo metodais pagrịstas suaugusiujų švietimas svarbus tuo, kad skatina remtis savo patirtimi, asmeniniais išgyvenimais ir pojūčiais. Dalyviai, naudodamiesi raiškos priemonemis, kurias mate scenoje, suvokia, kad šios jiems bus svetimos, neišplauks iš jų individualybės ir bus neitaigios. Tai vadinamieji štampai, stereotipai.

Kai kuriu autorių (Kazragytė, 2008; Tupikienè, 1998 ir kt.) nuomone, suaugusiujų švietimas, taikant kultūros ir meno ugdymo metodus, skatina kiekvieno asmens spontaniškumą, kūrybiškumo atradimą ir panaudojimą, padeda žmonèms atrasti savaji pajègumą. Teatras - tai socialinio pasikeitimo metodas, skatinantis aktyvų besimokančiujų įsitraukimą per teorines improvizacijas ir dramos proceso veiklas. İvairių technikų taikymas leidžia išlaisvinti pasikartojančias emocijas, spręsti problemas, ịveikti krizes, ieškoti ir atrasti alternatyvių bei priimtinų sau ir kitiems priemonių.

\section{Tyrimo rezultatai}

Vis labiau švietimas skverbiasi ị visuomenę, darydamas poveikị vienai ir kitai reikšmingai sričiai. Bendrųjų kompetencijų (BK) ịvaldymą, gebẻjimą jas panaudoti ịvairiose veiklose, jų kaitą lemia daugybè veiksnių, kuriems turi ịtakos politiniai, ekonominiai, socialiniai ir kultūriniai visuomenès gyvenimo pokyčiai. Siekdami veiksmingai dalyvauti visuomenès gyvenime, suaugusieji turi igyti ir plètoti bendrąsias kompetencijas, kurios yra būtinos, siekiant mokytis visą gyvenimą (MVG). Nuolatiné suaugusiųjų MVG programa pabrėžia, kad inovatyvumu grindžiamai visuomenei ir ekonomikai būtina geriau ir tikslingiau panaudoti savo žinias, ịūdžius bei gebejimus. Svarbiausi mokymosi visą gyvenimą (MVG) siekiniai, apibrèžti UNESCO Delorso pranešime „Mokymasis: vidinis lobis“ (1996), - tai mokymasis gyventi kartu, mokymasis žinoti, mokymasis veikti ir mokymasis būti. Bendrosiose Europos Komisijos rekomendacijose apie bendrąsias kompetencijas, akcentuojami gebejjimai, skatinantys socialinę integraciją, aktyvų pilietiškumą, produktyvų užimtumą (Recommendation of the European Parliament and of the Council, 
2006). Todèl svarbu, kad kiekvienas asmuo pagal savo poreikius ir išgales tobulètų kaip asmenybė, išreikšdamas pilietinę ir tautinę savimonę atskleistų bendrąsias kompetencijas. Taigi MVG esmę glaustai galima taip nusakyti: svarbiausia dèmesị sutelkti ị suaugusiojo asmenybès lavinimąsi, aktyvų, sąmoningą dalyvavimą ir gebejimą save realizuoti.

Apklausoje dalyvavusių respondentų amžius - nuo 18 iki 59 metų, $31 \%$ priklausė 50-59 metų amžiaus grupei. Aktyvūs buvo ir trečiosios amžiaus grupès suaugusieji (40-49 m.), t. y. ketvirtadalis visų dalyvavusiujų. Tyrime dalyvavo dauguma (64 \%) moteriškos lyties atstovių ir tik $36 \%$ - vyrų. Tai rodo, kad moterys ị tyrimą ịsitraukè aktyviau nei vyrai.

Dalyvavusių respondentų pasiskirstymas pagal išsilavinimą atskleidė, kad daugiausiai jų turejo aukštajị išsilavinimą (81\%). Nedidelè (septintadalis) dalis dalyvavusiųų turèjo profesinę kvalifikaciją (14\%) ir tik $5 \%$ turèjo vidurinị išsilavinimą. Gauti rezultatai atskleide, kad respondentų užimtumas yra įvairus, vis dèlto didesnè dauguma - dirbantys žmonès (76 \%). Tik $13 \%$ respondentų turi savo verslą. Tiriamuju gyvenamoji vieta - dominuoja miestas (94\%), tik maža dalis (13\%) dalyvavusiujų apklausoje gyvena kaimo ar gyvenvietès vietovèje.

Respondentų pageidauta, taikant rangavimo principą, ịvertinti savo asmenybės kultūrinio sąmoningumo kompetenciją. Grafoje „labai gerai“ pažymèjo gebėjimą pritaikyti meninès kūrybos elementus profesinèje veikloje ir kasdieniame gyvenime (51\%). Kiek mažiau, tačiau labai gerai vertino gebejimus bendrauti su kitais kultūros ir meno klausimais (45\%), plètoti ir turtinti savo kultūrinị akiratị (42 \%).

„Vidutiniški“" gebẻjimai pasiskirste maždaug vienodai, išskyrus gebejjimą pritaikyti meninès kūrybos elementus profesinèje veikloje ir kasdieniame gyvenime (27\%). „Silpnai“ ir „,nežinau“ pasiskirstė mažėjančia seka.

Paklausus tyrimo dalyvių apie kliūtis, su kuriomis susiduria lavindami asmenybės kultūrinio sąmoningumo kompetenciją, rezultatų skalèje išryškèjo įvairovė. Didžiausia kliūtis, respondentų nuomone, - laiko trūkumas (34\%). Kita respondentams svarbi priežastis - lěšų trūkumas (19\%). Tyrimas atskleidè, kad respondentus veikia ịvairios kliūtys, tokios kaip mokymosi paslaugų brangumas (9\%), kultūrinių renginių (6\%), mokymosi priemonių (3\%), vidinès drąsos (8\%), aplinkos pritarimo ir palaikymo (8\%) trūkumas, menkas sugebejjimas pritaikyti mokymosi metu ịgytas žinias, igūdžius ir gebėjimus (3\%), kt.

Nenoro mokytis $(1 \%)$ ar mokymosi prasmès nebuvimo (1\%) respondentai neišsakè. Tačiau išsamiau išanalizavus gautus rezultatus, galima teigti, kad suaugusiesiems dažniausiai trūksta vidinès paskatos arba aiškių motyvų nuolat lavintis ir tobulèti. Suaugusiojo poreikị mokytis lemia tam tikrų tikslų turejjimas. Taigi motyvacija gali gerokai išaugti, tada bus lengviau įveikti ir kliūtis. 
Tyrimo rezultatai atskleidè, kad asmens kultūrinio sąmoningumo gebèjimai yra aktualūs dalyvaujant visuomeninejje pilietinèje veikloje. Tai patvirtina gauti tyrimo rezultatai. Paaiškejjo, kad ryškiausiai gebẻjimai atsiskleidžia dalyvaujant vietos bendruomenès veikloje (gebejjimas pritaikyti meninès kūrybos elementus profesinëje veikloje ir kasdieniame gyvenime [41\%], gebejjimas bendrauti su kitais žmonėmis kultūros ir meno klausimais, plečiant ir turtinant kultūrini akiratị [36 \%], gebejjimas analizuoti meno kūrinius ir interpretuoti jų perduodamą žinią, vertinant jos aktualumą [31 \%]). Kultūrinio sąmoningumo gebejjimai padeda, siekiant skatinti naujas vietos bendruomenès veiklas. Paminètini šie gebėjimai: domejjimasis menu ir meno poreikio jautimas (30\%), gebẻjimas plèsti savo kultūrinį akiratị ir jị kryptingai turtinti (29\%). Vertinant respondentų pasisakymus paaiškejjo, kad kultūrinį sąmoningumą ir asmens pilietiškumą būtina suvokti kaip atsakomybès idejją. Tik asmuo, gebantis išsikelti tikslus ir ieškantis būdų, kaip juos realizuoti, gali būti atsakingas už tokio pasirinkimo pasekmes.

\section{Išvados}

1. Atlikta mokslinès literatūros analizè leidžia teigti, kad kultūrinio sąmoningumo fenomenas yra labai plati sąvoka, apimanti žinias apie tikrovę, apibūdinanti žmogaus gebėjimus stebèti, pažinti, suprasti save bei aplinką, atsakingai analizuoti ir suvokti savų ịsitikinimų, vertybių bei elgesio prasmes ir pagrịstumą, kritiškai mąstyti, t. y. atsiriboti nuo turimo žinojimo ir suvokimo, gebėti atskirti faktus ir nuomones, analizuoti bei interpretuoti realybės problemas ir dviprasmybes, kritiškai kvestionuoti socialinių reiškinių prielaidas, pasitelkus turimą patirtį, skatinti ne tik prasmines suvokimo transformacijas, bet ir imtis aktyvių veiksmų, siekiant realybę keičiančių ir išsilaisvinančių pokyčių.

2. Suaugusiujų švietimo procese taikomi tie patys pagrindiniai principai: motyvacija, laisvė, interesas, kultūrinè branda, žinių troškimas, autonomiškumas, refleksija. Suaugusiųų švietime taikoma nemažai meninio ugdymo metodų: vaidybiniai žaidimai, vaidmenys, improvizacija, veidrodis, dubliavimas, siužetais, savarankiškas turinio plètojimas, veiksmai su daiktais ir žmonėmis, kt. Suaugusiujų švietimas ir kultūrinio sąmoningumo ugdymo(si) procesas yra glaudžiai susiję, vienas kitą papildo, taip sudarant sąlygas formuotis brandžiai ir visapusiškai išsilavinusiai asmenybei. Mokslinès literatūros analizė leidžia skirti šiuos pagrindinius kultūrinio sąmoningumo ugdymo(si) principus: tai visą gyvenimą trunkantis procesas, pasirengimas nežinomai ateičiai; tai ne profesijos mokymasis, 
o savanoriškas gero, džiaugsmingo, prasmingo gyvenimo patyrimo bei galimybių plačiau atsiskleisti individo asmenybei ieškojimas, išmokimas keisti savo ịpročius, pasitelkti kitų motyvų, turèti kitų interesų.

3. Tyrimo rezultatai atskleidè, kad kultūrinio sąmoningumo kompetencija suaugusiojo gyvenime vis labiau populiarèja. Šiandien labiau nei kada nors anksčiau svarbu, kad suaugusieji įsitrauktų i pilietinę bendrystę, puoselètų toleranciją ir darnų ịvairių kultūrų sugyvenimą, tačiau suaugusiesiems dažniausiai trūksta vidinès paskatos arba aiškių motyvų nuolat lavintis ir tobulèti, o suaugusiojo poreiki mokytis lemia tam tikrų tikslų turèjimas. Tik asmuo, gebantis išsikelti tikslus ir ieškantis būdų, kaip juos realizuoti, gali būti atsakingas už tokio pasirinkimo pasekmes.

Gauta 20150130

Pasirašyta spaudai 20150317

\section{Literatūra}

Bendrieji visa gyvenima trunkančio mokymosi gebejimai. Europos orientaciniai metmenys. (2007). Liuksemburgas: Europos Bendrijų oficialiujų leidinių biuras, $12 \mathrm{p}$.

Bulajava, T. (2007). Suaugusiųų ugdymas: kritinio sąmoningumo link. Logos, Nr. 50: 167.

Chodzkienè, L. (2012). Europos Sajungos pedagogo tarpkultūrine komunikaciné kompetencija ir jos tobulinimo socioedukaciniai veiksniai. Daktaro disertacija. Vilnius: Edukologija.

Čeredaitè, A. (2006). Teatro metodų taikymas asmenybei ugdyti. Kultūros aktualijos, Nr. 2 (49): 10-14.

Gailienè, D., Bulotaitė, L., Sturlienė, N. (2004). Asmenybès ir bendravimo psichologija. Vilnius: Garnelis.

Gyventojų dalyvavimo kultūroje ir pasitenkinimo kultūros paslaugomis tyrimo ataskaita. (2014). Lietuvos Respublikos kultūros ministerija. Parengè: UAB „Socialinės informacijos centras“ ir UAB „ESTEP Vilnius“.

Kazragytė, V. (2008). Priešmokyklinio amžiaus vaiku vaidybos gebejjimu ugdymas. Monografija. Teatro edukologija. Vilnius: Vilniaus pedagoginio universiteto leidykla.

Kolbergyte, A., Indrašienė,V. (2012). Saviugdos formavimosi kontekstas. Socialinis darbas, Nr. 12(1): $137-150$.

Krasner, I. (1999). The Role of Culture in Language Teaching. Dialog on Language Instruction, Vol. 13, No. 1, 2 : 79-88.

Maceina, A. (2002). Pedagoginio vitalizmo problema. Raštai, t. 8. Vilnius.

Matonis, V. (2000). Meninis ugdymas nūdienèje kultūroje. Šiuolaikinès meninio ugdymo koncepcijos meninio ugdymo teorija JAV. Vilnius: Enciklopedija, p. 7-23.

Mažeikienė, N., Loher, D. (2008). Competence of University Teachers and Graduate Students for International Cooperation. Socialiniai mokslai, Nr. 2 (60): 48-65.

Melnikova, R. (2007). Integruotos teatro ir etikos pamokos. Vilnius: Enciklopedija.

Mezirow, J. (2000). Learning as Transformation: Critical Perspectives on a Theory in Progress. San Francisco: Jossey-Bass.

Mezirow, J. (1997). Transformative learning: Theory to practice. New directions for adult and continuing education, Vol. 74: 5-12. Available: Academic Search Premier.

Merriam, S. B., Caffarella, R. S., Baumgartner, L. M. (2007). Learning in Adulthood: A comprehensive guide. San Francisco: Jossey Bass.

Sikora, A. (2004). Susitikimai su filosofija: nuo Herakleito iki Huserlio. Vilnius: Alma littera.

Tupikienė, L. (1998). Mokyklos ir teatro sąlyčiu taškai. Mokykla ir teatras. Straipsnių rinkinys. Kaunas: Šviesa. 


\section{THE CULTIVATION OF CULTURAL CONSCIOUSNESS}

\section{Egidijus Stancikas}

Summary

The article introduces the theoretical insights relevant to a discussion of the cultivation of cultural consciousness. It relies on the following methodological precepts: Mezirow's principles of transformational change and experiential learning theories. On the basis of the foregoing principles, the article discusses the concept of cultural consciousness, which various writers define differently, and analyzes the substance of cultural consciousness as well as the methods involved in its cultivation. In the article the cultivation of cultural consciousness is presented as a vehicle for adult education.

Culture and education are undoubtedly among the most important factors, determining the society development level and the person's full-fledged well being in modern social life. The level of societal development is usually measured according to the results of these activities. Culture and education serve for reproduction of various forms of activity, accumulate and transform various forms of culture, build new potential of a subject, whose objective is to move to a higher societal and cultural level. The growth of society depends on the quality of culture and education, whereas adult life perspective depends on participation in cultural life and opportunities offered by the education system. The conception of cultural awareness is perceived as a personal competence, which manifests itself in the ability to recognize, respect and protect cultural diversity and to participate in socially valuable cultural activities. This concept is related to the education of culture, which in clades human knowledge, faith, art, morality, laws, customs and everything else, what a person acquires as apart of the society through continuous learning. Adult learning, personal and professional knowledge and development of competences contribute to creating unique significance of culture in personal and social life. This is especially relevant to an adult person, who has substantial life experience, knowledge and ability to choose forms, methods and techniques of development. For every persona way of development is an individual process that goes through integration into the society. Moreover, this broadens personal life and career opportunities. In order to survive and prosper the society must have a reliable mechanism of cultural transfer from generation to generation as well as working together to support learning autonomy of every member of society. The article explores the following questions: What is the concept of cultural consciousness and what guarantees its successful cultivation? 
From that, what was written, were made these conclusions:

1. Analysis of the scientific literature leads to the conclusions that the phenomenon of cultural awareness has a very vide concept encompassing knowledge about the reality, defining the human capacity to observe, acknowledge, to understand oneself and the surroundings, responsibly analyze and understand their own beliefs, values, behaviors and to think critically. In other words, to disassociate from the current knowledge and perception. Also to be able to separate facts and opinions, analyze and interpret problems of reality and ambiguity, critically question the assumptions of social phenomena. Moreover, by invoking current experience to encourage not only notional understanding of the transformations, but also to take active steps in order to alter reality changing and disengaging alterations.

2. Adult educational process is based on the same basic principles: motivation, freedom, interest, cultural maturity and curiosity, autonomy and reflection. In this kind of education is also used a whole pallet of artistic education methods, such as active games, roles, improvisation, mirror, backup, plots, self-content development, actions with objects and people, etc. In adult education and cultural awareness training (learning) process are a lot of links that complement one another, thereby assuring conditions for the formation of an educated and mature personality. Scientific literature review allows to exclude these main principles of cultural awareness training (learning): it is a lifelong process, preparation for an unknown future; this is not a vocational training, but self-contained good, joyful, meaningful life experience search, as well as searching for ways to reveal the individual's personality, learning to change one's habits, to guide oneself by the new motivations and interests.

3 . Results of the study revealed that the competence of cultural awareness is becoming more popular in adult life. Today, more than ever, it is important that adults engage in civic unity, tolerance and harmonious coexistence of different cultures. However, adults often lack the internal incentives or clear reasons to participate in permanent development and improvement, because that for an adult the need to learn comes from having certain goals. Only the person, who is able to set goals for oneself and who is looking for the ways to actualize them, can be responsible for the consequences of those choices. 
